\title{
NUMERICAL MODELLING OF MECHANICAL PHENOMENA IN CORONARY STENTS
}

\author{
Aneta Idziak-Jabłońska \\ Institute of Mechanical Technology, Czestochowa University of Technology \\ Czestochowa, Poland \\ idziak-jablonska@iop.pcz.pl
}

\begin{abstract}
Using the finite element method and mathematical models, this study determined mechanical characteristics of slotted-tube stents. A calculation model was developed and a type of material used for coronary slotted-tube stents was chosen in order to evaluate the biomechanical response to changes in geometrical parameters of stents. The numerical calculations were carried out using ADINA software. Stents were made of the four materials, i.e. austenitic steel 316L (Cr-Ni-Mo), cobalt-matrix alloy (Co-Cr-W-Ni) and two titanium-matrix alloys (Ti-13Nb-13Zr and Ti-6Al-7Nb). The effect of the stent geometry was analysed, with emphasis on examination of the effect of key mechanical phenomena such as expansion pressure and a suitable level of stress and plastic strain in stents. Analysis of the degree of foreshortening and dogboning after stent expansion was also carried out.
\end{abstract}

Keywords: stent, computational mechanics, FEM, mathematical modeling, mechanical properties, ADINA software

\section{Introduction}

It is hard to imagine current scientific and technological advances, including the development of mechanical sciences, without the emergence of information technology and numerical techniques. The use of computer methods in technology and science led to the development of new research fields, such as computational mechanics. This area of research is also referred to as numerical methods.

Mathematical analysis has led to the introduction of numerous descriptions of material objects in various fields of science, including mechanics. With the powerful capabilities of differential and integral calculus as a mathematical tool, the concept of continuous medium started to be broadly used, both concerning the continuous decomposition of matter in space (single-, two- or three-dimensional) and its evolution over time. On the other hand, computer methods allow for description of only discrete (discontinuous) structures. Therefore, in order to describe the concept of a continuous medium that naturally represents the mathematical abstraction, the time and space continuum has to be divided and replaced by a finite set of points, elements or ranges.

Since both computer memory and the number of operations that can be performed per time unit are finite, the mechanical processes and systems described by 
means of computer methods have to be represented by discrete and finite mathematical models.

Examinations of real phenomena that occur in the systems created in nature or those developed by humans require selection of information and a choice of significant factors that have an effect on their behaviour. The description of the phenomena analysed in mechanics is presented by means of mathematical equations. These are mostly differential equations or a standard equation defined in a certain region $\Omega$, where the examined phenomenon occurs. In such cases, the equations represent the mathematical model of the phenomenon. This mainly means the continuous or discrete model. These equations are to be complemented by the boundary conditions that must be satisfied on the boundary of the region Q, and also the initial equation, which determines the state of the phenomenon at a certain time assumed as initial. Partial differential equations with boundary and initial conditions represent the boundary-initial value problem [1].

The ability to solve boundary-initial value problems in mechanics is of key importance to the analysis of phenomena, predicting their patterns and rational design of the system they are supposed to occur in. Definition and solving boundary-initial value problems can be mainly used for solving the problems that have a direct practical importance. The boundary-initial value problems can be solved by means of the numerical and analytical methods.

The use of analytical methods is, however, limited, since for any region $\Omega$, finding the strict solution to the boundary-initial value problem is usually impossible. The only universal method to solve the boundary-initial value problems is to use numerical methods. It is numerical methods that represent one of the principal mainstreams in the development of contemporary technology and science. The use of these methods allows for computer simulation of real phenomena with physical nature, including mechanical phenomena [2].

Computer modelling and simulation represent the extension of the scope of theoretical sciences, where obtaining new cognitive results is based mainly on mathematical models. These models describe physical phenomena and are fundamental to scientific theories. However, simulation can offer much more e.g. it can be used for exploration of new theories and designing new experiments to verify these theories.

There are a number of computer methods that allow for solving boundary-initial value problems. The main methods include [3]:

- finite element method (FEM),

- boundary element method (BEM),

- finite difference method (FDM).

The finite element method is at the forefront of the computational methods since it is the commonly used standard for engineering computations. The finite element method is an approximate method of solving partial differential equations.

The major benefit of MES is its capability to simulate the processes for elements with complex shapes and to obtain the results for which analytical calcula- 
tions would be impossible or very difficult. The problem can be modelled in the computer memory, without the need for designing a prototype, which makes the design process substantially easier and faster [4].

Computational analyses have been used in many areas of biomechanics and biomedical engineering. Current challenges are connected with the use of examinations based on computer simulations in medicine, especially those concerning soft and hard tissue and examinations of biological systems at the level of cells and entire body organs.

\section{Numerical model of a coronary stent}

The finite element method (FEM) is a powerful tool for evaluation of biomechanical behaviours of complex stent structures. The tool optimizes mechanical and physical properties of stents, especially when physical methods are difficult or impossible to be used and numerical modelling remains the only alternative. The major advantage of numerical modelling is that it answers the question of "What if?" Therefore, computational models represent a valuable part of designing stents and the developing processes. As numerical models, they are always very close to real conditions. In general, a model of a finite element of the stent is determined by its geometry, material properties, adequate load and boundary conditions.

Coronary stents have revolutionized invasive cardiology. They ensure successful treatment of coronary disease, repair blood vessels and maintain the free flow of blood in these vessels. If stents can be implanted, they offer a perfect alternative to radical surgical interventions.

Numerical computations have mainly concerned the distribution of stresses and displacements of individual elements in the adopted system model. This allows for optimization of geometrical characteristics of the implant and its biomechanical properties [5]. Numerical simulations can be successfully used for determination of a number of parameters which are critical to the clinical assessment of specific stent designs e.g. stent shortening after expansion. In the present study, the numerical analysis was performed based on the finite element method using the commercially available ADINA v.8.8 software [6].

Individual stages of the study concerned the development of [7]:

- geometrical model of the coronary stent,

- discrete model of the coronary stent,

- numerical model of the coronary stent using the finite element method,

- model after modification.

\subsection{Mathematical model}

The study analysed equilibrium equations, without body forces, used in the velocity form i.e. $[2,8]$ : 


$$
\operatorname{div}(\dot{\boldsymbol{\sigma}}(\mathbf{x}, t))=\mathbf{0}, \dot{\boldsymbol{\sigma}}=\dot{\boldsymbol{\sigma}}^{T}
$$

where $\sigma=\sigma\left(\sigma_{i j}\right)$ is stress tensor, $\mathbf{x}=\mathbf{x}\left(x_{i}\right)$ is vector of location of the given particle (point).

The equation (1) is supplemented with constitutive relationships, which, in general notation with the assumption of additivity of strain, are given by

$$
\dot{\boldsymbol{\sigma}}=\mathbf{D} \cdot\left(\dot{\boldsymbol{\varepsilon}}-\dot{\boldsymbol{\varepsilon}}^{p}\right)
$$

and boundary conditions:

- in the internal surface of the stent (boundary $\Gamma_{p}$ ), there is the stress vector (pressure p)

$$
\left.(\dot{\boldsymbol{\sigma}}(\mathbf{x}, t) \circ \mathbf{n})\right|_{\Gamma_{p}}=-\dot{\mathbf{p}}
$$

- in the nodes of the cross-section perpendicular to the axis $x_{1}=\mathrm{x}$ (boundary $\Gamma_{u}$ ), degrees of freedom were removed in the direction $x$, i.e.

$$
\left.\dot{\mathbf{U}}_{x}(\mathbf{x}, t)\right|_{\Gamma_{u}}=\mathbf{0}
$$

whereas in one of the external nodes of the cross-section $\Gamma_{u}$, the degrees of freedom in the directions $\mathrm{y}$ and $\mathrm{z}$ and rotation were removed i.e.

$$
\left.\dot{\mathbf{U}}_{y}(\mathbf{x}, t)\right|_{\Gamma_{u}}=\mathbf{0},\left.\dot{\mathbf{U}}_{z}(\mathbf{x}, t)\right|_{\Gamma_{u}}=\mathbf{0}
$$

where: $\mathbf{D}$ is elasticity matrix, $\boldsymbol{\varepsilon}=\boldsymbol{\varepsilon}\left(\varepsilon_{i j}\right)$ is the tensor of total strain, $\boldsymbol{\varepsilon}^{p}=\boldsymbol{\varepsilon}^{p}\left(\varepsilon_{i j}^{p}\right)$ is plastic strain tensor, $\mathbf{n}$ is the vector which is normal to the internal stent surface and the sign $\left(^{\circ}\right)$ means an incomplete inner product.

In the mathematical and engineering notation (with consideration for symmetry), stress and strain tensors have the components:

$$
\boldsymbol{\sigma}=\left(\begin{array}{l}
\sigma_{11} \\
\sigma_{22} \\
\sigma_{33} \\
\sigma_{12} \\
\sigma_{23} \\
\sigma_{13}
\end{array}\right)=\left(\begin{array}{c}
\sigma_{x} \\
\sigma_{y} \\
\sigma_{z} \\
\sigma_{x y} \\
\sigma_{y z} \\
\sigma_{x z}
\end{array}\right), \quad \boldsymbol{\varepsilon}^{e}=\left(\begin{array}{c}
\varepsilon_{11}-\varepsilon_{11}^{p} \\
\varepsilon_{22}-\varepsilon_{22}^{p} \\
\varepsilon_{33}-\varepsilon_{33}^{p} \\
\varepsilon_{12}-\varepsilon_{12}^{p} \\
\varepsilon_{23}-\varepsilon_{23}^{p} \\
\varepsilon_{13}-\varepsilon_{13}^{p}
\end{array}\right)=\left(\begin{array}{c}
\varepsilon_{x}-\varepsilon_{x}^{p} \\
\varepsilon_{y}-\varepsilon_{y}^{p} \\
\varepsilon_{z}-\varepsilon_{z}^{p} \\
\varepsilon_{x y}-\varepsilon_{x y}^{p} \\
\varepsilon_{y z}-\varepsilon_{y z}^{p} \\
\varepsilon_{x z}-\varepsilon_{x z}^{p}
\end{array}\right)
$$

where $\boldsymbol{\varepsilon}^{e}=\boldsymbol{\varepsilon}^{e}\left(\varepsilon_{i j}^{e}\right)$ is the plastic strain tensor. 
For isotropic materials, the elasticity matrix in $3 \mathrm{D}$ tasks is

$$
\mathbf{D}=\left(\begin{array}{cccccc}
2 \mu+\lambda & \lambda & \lambda & 0 & 0 & 0 \\
\lambda & 2 \mu+\lambda & \lambda & 0 & 0 & 0 \\
\lambda & \lambda & 2 \mu+\lambda & 0 & 0 & 0 \\
0 & 0 & 0 & 2 \mu & 0 & 0 \\
0 & 0 & 0 & 0 & 2 \mu & 0 \\
0 & 0 & 0 & 0 & 0 & 2 \mu
\end{array}\right)
$$

where $\mu=\mu(E, v)$ and $\lambda=\lambda(E, v)$ are Lamé constants (constant $\mu$ is shear modulus) depending on Young's modulus and Poisson's ratio:

$$
\mu=\frac{E}{2(1+v)}, \lambda=\frac{v E}{(1+v)(1-2 v)}
$$

The developed model was used for numerical computations.

\subsection{Description of the material model}

There have been a number of publications devoted to the problems of modelling of stents made of $316 \mathrm{~L}$ steel or alloys based on a cobalt matrix, but only the study [9] attempted to analyse stents made of Ti-6Al-4V alloy, apart from the previously mentioned materials. Therefore, the aim of the present study was to develop stent models made from two alloys based on titanium matrix and compare them with the most popular materials, i.e. Cr-Ni-Mo and Co-Cr-W-Ni. Titanium-matrix alloys analysed in this study, i.e. Ti-6Al-7Nb and Ti-13Nb-13Zr, have been mostly used in implantology due to their properties concerning corrosion resistance and biotolerance.

An elastic-plastic model of material with isotropic strengthening was adopted in the analysis of mechanical phenomena in stents. Plastic deformations were determined according to the associated plastic flow law $[2,8,10,11]$

$$
\dot{\boldsymbol{\varepsilon}}^{\mathrm{p}}=\dot{\Lambda} \frac{\partial f}{\partial \boldsymbol{\sigma}}, \quad \dot{f}=0, \quad f=0
$$

where $\Lambda$ is a scalar plastic multiplier, $f=f(\boldsymbol{\sigma}, Y)$ is the flow function depending on the stress tensor and yield stress.

The plastic flow model with the Huber-Mises yield criterion and isotropic hardening was used to determine plastic strains. The plastic flow function was adopted as:

$$
f=\sigma_{e f}-Y\left(\varepsilon_{e f}^{\mathrm{p}}, \kappa\right)=0
$$


where $\sigma_{e f}$ is effective stress, $\varepsilon_{e f}^{\mathrm{p}}$ is effective plastic strain, $Y=Y\left(\varepsilon_{e f}^{p}, \kappa\right)$ is yield stress after effective plastic strain $\varepsilon_{e f}^{p}$, i.e.:

$$
Y\left(\varepsilon_{e f}^{\mathrm{p}}, \kappa\right)=Y_{0}+Y_{H}\left(\varepsilon_{e f}^{\mathrm{p}}, \kappa\right)
$$

where: $Y_{0}$ is the yield point of material at the absence of plastic strain, $Y_{H}=Y_{H}\left(\varepsilon_{e f}^{p}, \kappa\right)$ is excess stress over yield point resulting from material hardening.

Huber-Mises equivalent (effective) stresses were determined as follows $[10,11]$ :

$$
\sigma_{e f}=\sqrt{\frac{3}{2} S_{i j} S_{i j}}, i, j=1,2,3
$$

where $\mathbf{S}=\boldsymbol{\sigma}-\frac{1}{3} \mathbf{I}($ vestigal $(\boldsymbol{\sigma}))$ is the stress deviator tensor.

Differentiation of (10) with respect to the stress tensor and using (12) and (9) leads to:

$$
\dot{\boldsymbol{\varepsilon}}^{\mathrm{p}}=\dot{\Lambda} \frac{3 \mathbf{S}}{2 Y}
$$

With unloading, neutral and loading conditions, the following relationships can be written

$$
\dot{\boldsymbol{\varepsilon}}^{\mathrm{p}}=\left\{\begin{array}{cc}
\dot{\Lambda} \frac{3 \mathbf{S}}{2 Y}, & \dot{\Lambda}>0, \\
0, & \dot{\Lambda} \leq 0
\end{array}\right.
$$

Speed of effective plastic strain is described by the equation:

$$
\dot{\varepsilon}_{e f}^{p}=\sqrt{\frac{2}{3} \dot{\boldsymbol{\varepsilon}}^{\mathrm{p}} \cdot \dot{\boldsymbol{\varepsilon}}^{\mathrm{p}}}=\sqrt{\frac{2}{3} \dot{\varepsilon}_{i j}^{p} \dot{\varepsilon}_{i j}^{p}}, i, j=1,2,3
$$

Substitution of (15) with (13) yields:

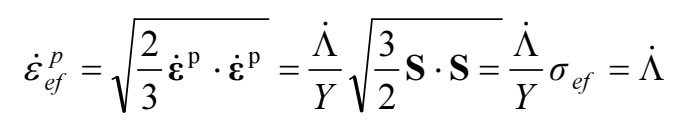

The equation (16) suggests that the scalar plastic multiplier represents effective plastic strain.

The equivalent plastic strain (effective plastic strain) was defined as:

$$
\varepsilon_{e f}^{p}=\int_{0}^{t} \dot{\varepsilon}_{e f}^{p} d t
$$


This quantity presents the total accumulation of plastic strain generated during load around the stent structure point [12].

Material properties adopted for computations were consistent with the ranges specified in the standards [13-16]:

a) PN - ISO 5832-1 for 316L steel,

b) PN - ISO 5832-5 for L605 cobalt-matrix alloy,

c) ASTM F1295 $(\alpha+\beta)$ for Ti-6Al-7Nb titanium-matrix alloy,

d) ASTM F1713 ( $\beta$ ) for Ti-13Nb-13Zr titanium-matrix alloy.

Table 1 presents the material data adopted in the study.

Table 1

Material properties for the models studied

\begin{tabular}{|l|c|c|c|c|}
\hline \multirow{2}{*}{\multicolumn{1}{|c|}{ Material properties }} & \multicolumn{4}{c|}{ Material } \\
\cline { 2 - 5 } & Cr-Ni-Mo & Co-Cr-W-Ni & Ti-6Al-7Nb & Ti-13Nb-13Zr \\
\hline Young's modulus E [MPa] & 205000 & 243000 & 106000 & 79000 \\
\hline Poisson's ratio $v$ & 0.33 & 0.3 & 0.35 & 0.34 \\
\hline Tensile strength $\mathrm{R}_{\mathrm{m}}[\mathrm{MPa}]$ & 470 & 917 & 1000 & 1030 \\
\hline Yield point $\mathrm{R}_{\mathrm{p} 0.2}[\mathrm{MPa}]$ & 195 & 476 & 900 & 900 \\
\hline $\begin{array}{l}\text { Max. allowable effective } \\
\text { plastic strain }\end{array}$ & 0.4 & 0.65 & 0.12 & 0.15 \\
\hline Density $\rho\left[\mathrm{kg} / \mathrm{m}^{3}\right]$ & 7850 & 9270 & 4510 & 4430 \\
\hline
\end{tabular}

\subsection{Geometry of coronary stents}

The models of stents presented in the literature were over $20 \mathrm{~mm}$ in length, but from the analysis of the cardiological references, a vast majority (over $70 \%$ ) of stenoses treated by coronary interventions did not exceed the length of $15 \mathrm{~mm}$. Therefore, this study modelled the stent with the length of $12 \mathrm{~mm}$.

Modelling was performed for a slotted-tube stent. Model geometry was inspired by the Palmaz-Schatz ${ }^{\mathrm{TM}}$ stent design [17].

Total stent length was constant, $\mathrm{L}=12 \mathrm{~mm}$. The internal radius of the stent studied was $\mathrm{R}=0.5 \mathrm{~mm}$ (see Fig. 1). Stent models were analysed for two different numbers of segments, i.e. 12 and 15. Dimensions of individual parameters depending on the number of segments are contained in Table 2. Three stents with different wall thickness were analysed: $G=0.08,0.1$ and $0.12 \mathrm{~mm}$. The individual lengths of the stent (D1, D2, D3, D4) were not changed with the increase in the number of segments. The variable parameters were K11, K12 (angles of connectors) and Kp1 and $\mathrm{Kp} 2$ (angles between mesh arms of the segment), which depended on the number of stent segments [18]. 
Values of individual stent parameters

\begin{tabular}{|c|c|c|c|c|c|c|c|}
\hline $\begin{array}{c}\text { Number of } \\
\text { segments }\end{array}$ & $\begin{array}{c}\mathrm{K} 11=\mathrm{K} 12 \\
{\left[{ }^{\circ}\right]}\end{array}$ & $\begin{array}{c}\mathrm{Kp} 1=\mathrm{Kp} 2 \\
{\left[{ }^{\circ}\right]}\end{array}$ & $\begin{array}{c}\mathrm{D} 1 \\
{[\mathrm{~mm}]}\end{array}$ & $\begin{array}{c}\mathrm{D} 2 \\
{[\mathrm{~mm}]}\end{array}$ & $\begin{array}{c}\mathrm{D} 3 \\
{[\mathrm{~mm}]}\end{array}$ & $\begin{array}{c}\mathrm{D} 4 \\
{[\mathrm{~mm}]}\end{array}$ & $\begin{array}{c}\mathrm{R} \\
{[\mathrm{mm}]}\end{array}$ \\
\hline 12 & 3 & 12 & 0.5 & 1.6 & 0.3 & 0.25 & 0.8 \\
\hline 15 & 2 & 10 & 0.5 & 1.6 & 0.3 & 0.25 & 0.8 \\
\hline
\end{tabular}

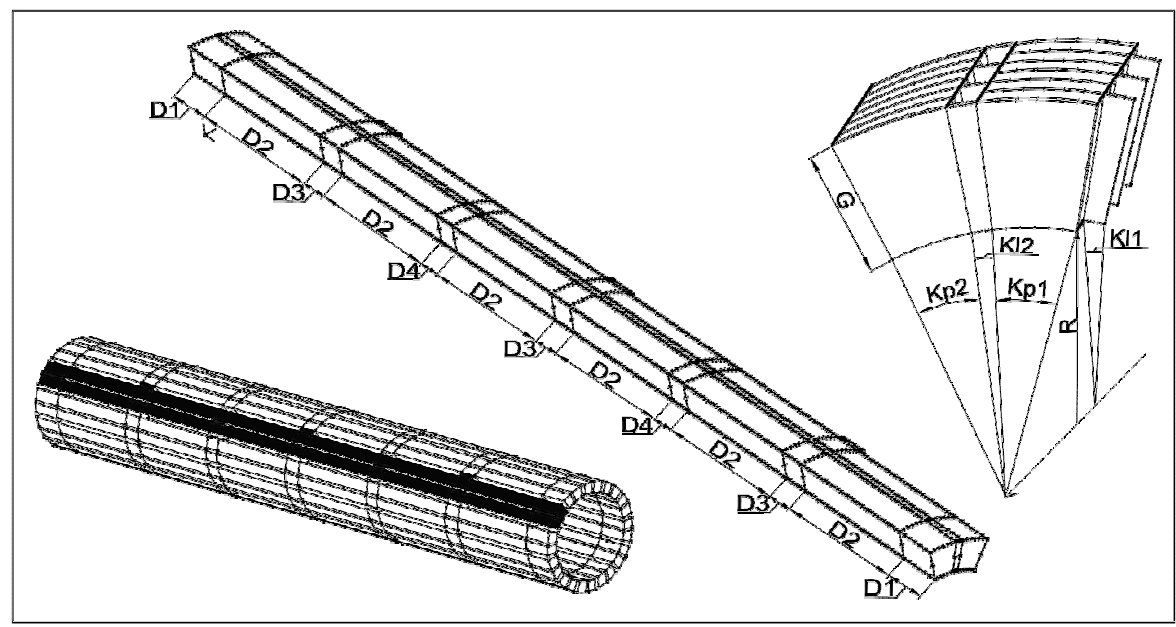

Fig. 1. Example of geometrical stent model

\subsection{Type of node elements}

The computations using finite element methods were based on a grid of elements for the designed geometrical models. Discretization was carried out by means of the element of the 3D SOLID type and the analysed cases were discretized with eight-node elements. The number of nodes in the models analysed ranged from 127260 to 159075 for the stents with segments from 12 to 15 , respectively. One segment of the stent contained 6120 elements of the 3D type. The total number of 3D elements obtained for the cases studied was from 73584 to 97980 .

Migliavacca et al. [19] demonstrated that the numerical simulations of stents are sensitive to the improvement of the FEM grid. Therefore, grid validation was performed, and it was found that the current grid was sufficient for further analysis.

Figure 2 presents an example of a geometrical model of a coronary stent with the superimposed finite element mesh in the non-expanded (Fig. 2a) and expanded stents (Fig. 2b). 


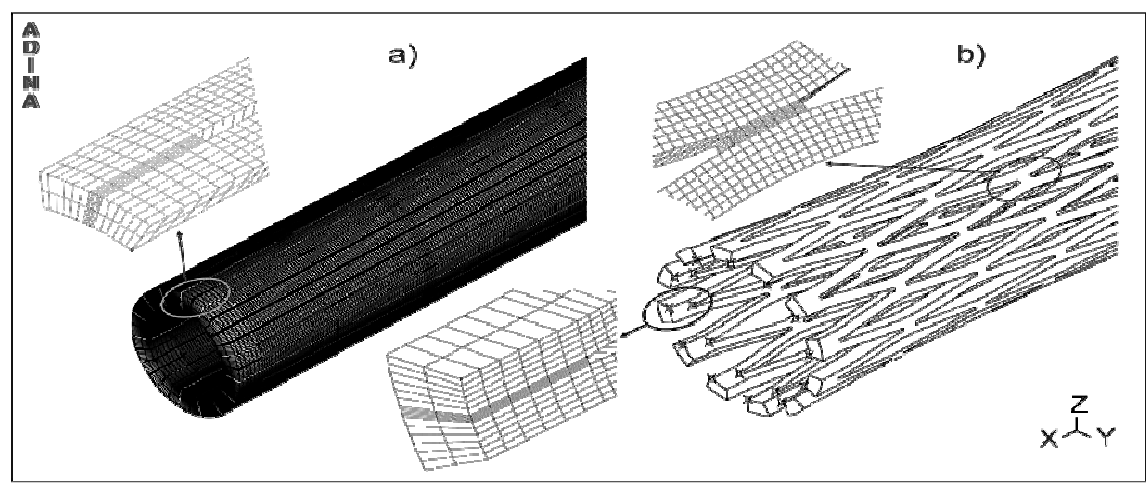

Fig. 2. Calculation model of a coronary stent: a) with the superimposed finite element mesh in the non-expanded stent, b) with the superimposed finite element mesh in the expanded stent

\subsection{Boundary conditions and load}

Most stents are designed to be used in coronary arteries with an internal diameter $>3.0 \mathrm{~mm}$. However, clinical tests have demonstrated that around $40 \%$ of lesions in coronary arteries qualify patients for stent implantation in arteries with diameters $<3.0 \mathrm{~mm}$. Therefore, the study analysed stents expanded to the diameter of $3 \mathrm{~mm}$.

Numerical computations required determination of initial and boundary conditions which would allow for modelling of the phenomena occurring in the real object. For this reason, the following assumptions were made:

- expansion pressure was applied to the internal surface of the stent and was defined as a pressure used in the stent to reach the expected diameter (Fig. 3);

- the stent was expanded until the internal diameter of a healthy coronary vessel was obtained $(3.0 \mathrm{~mm})$.

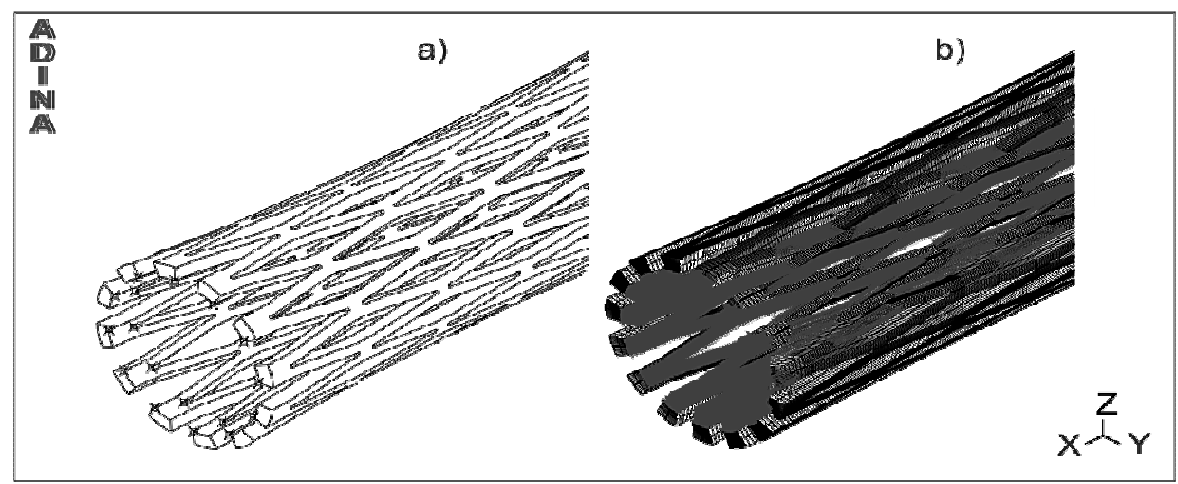

Fig. 3. Computational model of coronary stent: a) without pressure imposed on the internal stent surface, b) distribution of pressure during expansion 
The following assumptions were made to determine mechanical properties of stents:

- implantation at low expansion pressure;

- limitation of foreshortening $(\leq 2 \%)$;

- low increase of the diameter in the beginning and end of the implant (Min dogboning).

For this model and the assumed geometrical stent characteristics, the state of stresses and strain was determined for various expansion pressures used in clinical practice and foreshortening and dogboning were evaluated.

\subsection{Model modification}

The study assumed that numerical analysis would concern the effect of variable stent geometry on the properties of the expanded stents. The aim of the study was to suggest potential design parameters which can limit the risk of restenosis caused by shortening or uneven extension of the implant in the beginning and the end of the stent [20].

Model modification was performed by changing geometrical characteristics of the stent. Optimization required parameterization of the geometrical model, which is represented by the set of variable shapes instead of constant geometrical values of the model. It was rebuilt and again discretized according to the updated design variables.

As mentioned before, the analysis concerned stent models for two different numbers of segments: 12 and 15, with three different values of wall thickness: $\mathrm{G}=0.08,0.1$ and $0.12 \mathrm{~mm}$. Angles of connectors K11, K12 and angles of wires Kp1 and Kp2 were also variable and dependent on the number of stent segments. These three parameters (number of segments, wall thickness and angles) were optimized in this study. Figure 4 presents stent models with 12 and 5 segments.

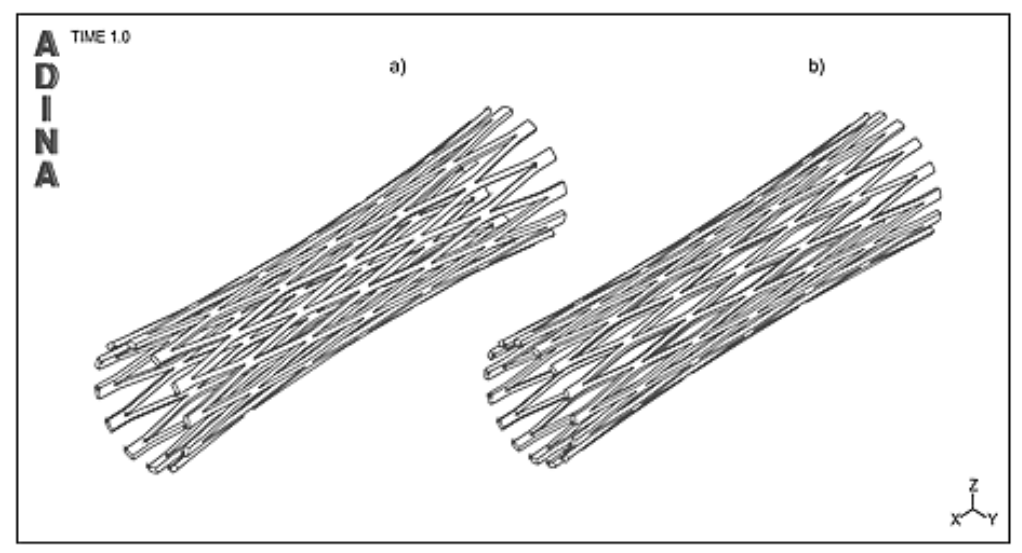

Fig. 4. Stent models with a different number of segments: a) 12 segm., b) $15 \mathrm{segm}$. 


\section{Results of numerical computations}

The present study analysed Palmaz-Schat ${ }^{\mathrm{TM}}$ stents using the finite element method. The stents used in the study were expanded with the pressure applied from the inside in order to determine their mechanical characteristics. The author evaluated the effect of the analysed geometries of coronary stents with emphasis on the importance of key parameters such as implant pressure, stress and plastic deformities in coronary stents, for various utility materials.

The parameters that are essential in terms of clinical assessment of a particular stent design e.g. shortening of the stent after expansion and evaluation of the unevenness of the increase in the diameter in the proximal and distal ends of the stent were also determined $[21,22]$. Foreshortening was calculated from the formula:

$$
\text { Foreshortening }=\frac{L-L^{\text {load }}}{L} \cdot 100 \%
$$

where: $L$ - initial stent length, $L^{\text {load }}$ - stent length at maximal load pressure.

Furthermore, uneven increase in implant diameter in the beginning and end of the stent (dogboning) was evaluated from the formula [23]:

$$
\text { Dogboning }=\frac{D_{\text {distal }}-D_{\text {central }}}{D_{\text {central }}} \cdot 100 \%
$$

where: $D_{\text {distal }}$ - stent diameter in the distal part, $D_{\text {central }}$ - stent diameter in the central part.

Table 3 contains the results of numerical analysis for four analysed materials. The table contains the values of expansion pressure obtained for individual cases of stents and the effective stresses, plastic strain and degree of shortening and increase in the diameter in the beginning and the end of the stent [7].

As mentioned before, the stent was expanded until the internal diameter of a healthy coronary artery was obtained $(3.0 \mathrm{~mm})$. Stent expansion pressure was adjusted to ensure reaching the required stent diameter. This pressure was necessary for plastic deformation of the stent from the material used. A gradual linear increase was ensured on the internal stent surface. The pressure for all the analysed cases ranged from 0.071 to $0.552 \mathrm{MPa}$. The computations revealed that the stent with the highest number of segments required the highest pressure. Furthermore, the results demonstrated that the increase in stent wall thickness led to an increase in expansion pressure by ca. $30 \%$ on average.

Another stage of the study concerned determination of maximal and minimal stresses averaged in the nodes for individual stent types. Varied distributions of effective stents were obtained for the materials analysed. 
Table 3

Results of numerical analysis

\begin{tabular}{|c|c|c|c|c|c|c|c|c|}
\hline \multirow{2}{*}{$\begin{array}{c}\text { Stent wall } \\
\text { thickness } \\
\text { G } \\
{[\mathrm{mm}]}\end{array}$} & \multirow{2}{*}{$\begin{array}{c}\text { Expansion } \\
\text { pressure } \\
p \\
{[\mathrm{MPa}]}\end{array}$} & \multirow{2}{*}{$\begin{array}{c}\text { Stent } \\
\text { diameter } \\
{[\mathrm{mm}]}\end{array}$} & \multicolumn{2}{|c|}{$\begin{array}{c}\text { Effective stress } \\
\sigma_{\text {sr. }}[\mathrm{MPa}]\end{array}$} & \multirow{2}{*}{$\begin{array}{l}\text { Plastic } \\
\text { strain } \\
\varepsilon\end{array}$} & \multirow{2}{*}{$\begin{array}{c}\text { Displace- } \\
\text { ment - X } \\
{[\mathrm{mm}]}\end{array}$} & \multirow{2}{*}{$\begin{array}{c}\text { Foreshorten- } \\
\text { ing } \\
{[\%]}\end{array}$} & \multirow{2}{*}{$\begin{array}{c}\text { Dogboning } \\
{[\%]}\end{array}$} \\
\hline & & & MAX & MIN & & & & \\
\hline \multicolumn{9}{|c|}{ Cr-Ni-Mo stent } \\
\hline \multicolumn{9}{|c|}{ 12-SEGMENT STENT } \\
\hline 0.08 & 0.108 & 3.01 & 336.1 & 2.088 & 0.105 & 0.0945 & 0.787 & 30.42 \\
\hline 0.1 & 0.142 & 3.01 & 334.0 & 1.519 & 0.103 & 0.0951 & 0.792 & 26.26 \\
\hline 0.12 & 0.178 & 3.0 & 341.1 & 2.204 & 0.101 & 0.1141 & 0.951 & 23.97 \\
\hline \multicolumn{9}{|c|}{ 15-SEGMENT STENT } \\
\hline 0.08 & 0.071 & 2.994 & 339.7 & 1.070 & 0.072 & 0.0506 & 0.422 & 21.41 \\
\hline 0.1 & 0.093 & 2.998 & 334.8 & 0.182 & 0.071 & 0.0542 & 0.452 & 17.85 \\
\hline 0.12 & 0.117 & 3.008 & 330.2 & 0.193 & 0.070 & 0.0509 & 0.425 & 15.16 \\
\hline \multicolumn{9}{|c|}{ Co-Cr-W-Ni stent } \\
\hline \multicolumn{9}{|c|}{ 12-SEGMENT STENT } \\
\hline 0.08 & 0.235 & 3.0 & 849.0 & 1.017 & 0.104 & 0.1228 & 1.02 & 47.49 \\
\hline 0.1 & 0.309 & 2.996 & 838.5 & 1.703 & 0.099 & 0.1877 & 1.564 & 39.09 \\
\hline 0.12 & 0.390 & 3.01 & 825.2 & 2.483 & 0.098 & 0.0718 & 0.598 & 32.13 \\
\hline \multicolumn{9}{|c|}{ 15-SEGMENT STENT } \\
\hline 0.08 & 0.155 & 2.996 & 829.9 & 0.508 & 0.069 & 0.07967 & 0.664 & 32.80 \\
\hline 0.1 & 0.204 & 3.002 & 805.8 & 0.603 & 0.066 & 0.07285 & 0.61 & 26.13 \\
\hline 0.12 & 0.257 & 2.998 & 782.0 & 0.506 & 0.064 & 0.0597 & 0.497 & 21.57 \\
\hline \multicolumn{9}{|c|}{ Ti-13Nb-13Zr stent } \\
\hline \multicolumn{9}{|c|}{ 12-SEGMENT STENT } \\
\hline 0.08 & 0.275 & 3.0 & 1196.0 & 0.371 & 0.039 & 0.1471 & 1.23 & 50.82 \\
\hline 0.1 & 0.376 & 3.0 & 1183.0 & 0.128 & 0.040 & 0.1238 & 1.03 & 45.35 \\
\hline 0.12 & 0.488 & 3.0 & 1192.0 & 0.316 & 0.040 & 0.1158 & 0.97 & 40.32 \\
\hline \multicolumn{9}{|c|}{ 15-SEGMENT STENT } \\
\hline 0.08 & 0.164 & 3.002 & 1045.0 & 0.169 & 0.012 & 0.0863 & 0.72 & 34.74 \\
\hline 0.1 & 0.223 & 2.998 & 1102.0 & 0.135 & 0.013 & 0.0732 & 0.61 & 29.56 \\
\hline 0.12 & 0.288 & 3.006 & 1154.0 & 0.182 & 0.1014 & 0.0651 & 0.54 & 25.35 \\
\hline \multicolumn{9}{|c|}{ Ti-6Al-7Nb stent } \\
\hline \multicolumn{9}{|c|}{ 12-SEGMENT STENT } \\
\hline 0.08 & 0.316 & 3.004 & 1160.0 & 1.386 & 0.059 & 0.1405 & 1.17 & 59.35 \\
\hline 0.1 & 0.429 & 3.002 & 1180.0 & 2.35 & 0.059 & 0.1301 & 1.08 & 52.57 \\
\hline 0.12 & 0.552 & 3.002 & 1195.0 & 0.832 & 0.058 & 0.1174 & 0.98 & 46.73 \\
\hline \multicolumn{9}{|c|}{ 15-SEGMENT STENT } \\
\hline 0.08 & 0.2 & 3.01 & 1235.0 & 0.589 & 0.026 & 0.0981 & 0.82 & 40.13 \\
\hline 0.1 & 0.269 & 3.0 & 1270.0 & 0.395 & 0.025 & 0.0827 & 0.69 & 34.53 \\
\hline 0.12 & 0.345 & 3.0 & 1265.0 & 0.219 & 0.026 & 0.0807 & 0.67 & 29.76 \\
\hline
\end{tabular}


The values of effective stresses exceeded their conventional yield limit for all the analysed materials, which caused a constant deformation of stent geometries. This condition is necessary for a proper process of implantation of the stent in the coronary vessel. The Cr-Ni-Mo stent was characterized by the lowest values of effective stresses compared to stresses obtained for other analysed materials, with the highest values of stresses documented for Ti- $6 \mathrm{Al}-7 \mathrm{Nb}$ stents. The highest values of stresses occurred in connectors and branches of the stent structure. Figure 5 presents the example distributions of maximal and minimal stresses obtained during the computations.

a)

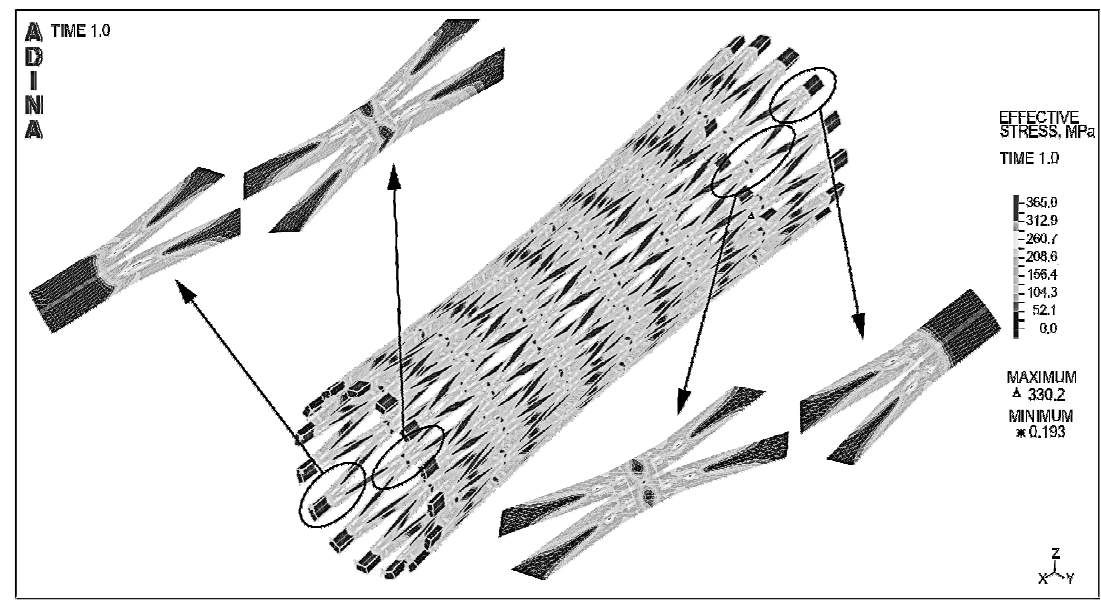

b)

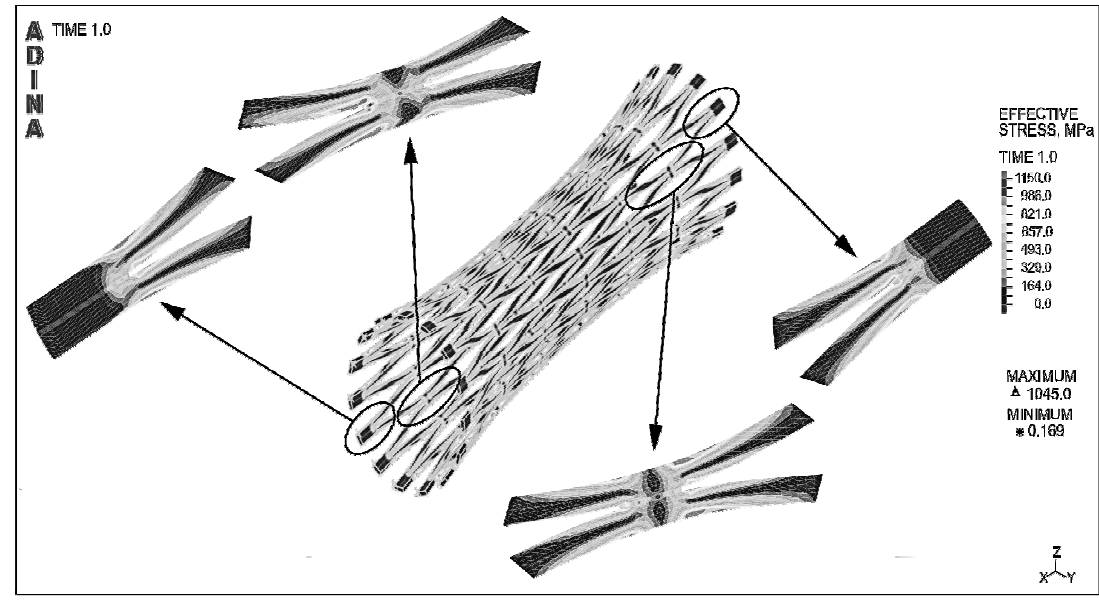

Fig. 5. Examples of distributions of averaged effective stresses in stent nodes: a) Cr-Ni-Mo stent, 15 segm., wall thickness $0.12 \mathrm{~mm}$, b) Ti-6Al-7Nb stent, 15 segm., wall thickness $0.1 \mathrm{~mm}$

The analysis showed that for all materials, maximal plastic strain was observed in stent branches in the areas of the highest values of plastic strain. The lowest 
values of strain were recorded for the stent with the lowest Young's modulus i.e. in $\mathrm{Ti}-13 \mathrm{Nb}-13 \mathrm{Zr}$ titanium-matrix alloy, whereas the highest values were found for the cobalt alloy, for which Young's modulus had the highest value among all the analysed materials [24].

Foreshortening analysed in the study was defined as minimal longitudinal shortening during expansion. Excessive degree of shortening leads to the unfavourable shear between the stent and the coronary artery. With the constant assumption, values of foreshortening for the stent 12 and 15 remained within the range adopted for computations. For these stents, foreshortening ranged from 0.422 to $0.951 \%$. Figure 6 presents a stent in the non-expanded form and after expansion with a noticeable degree of stent foreshortening.

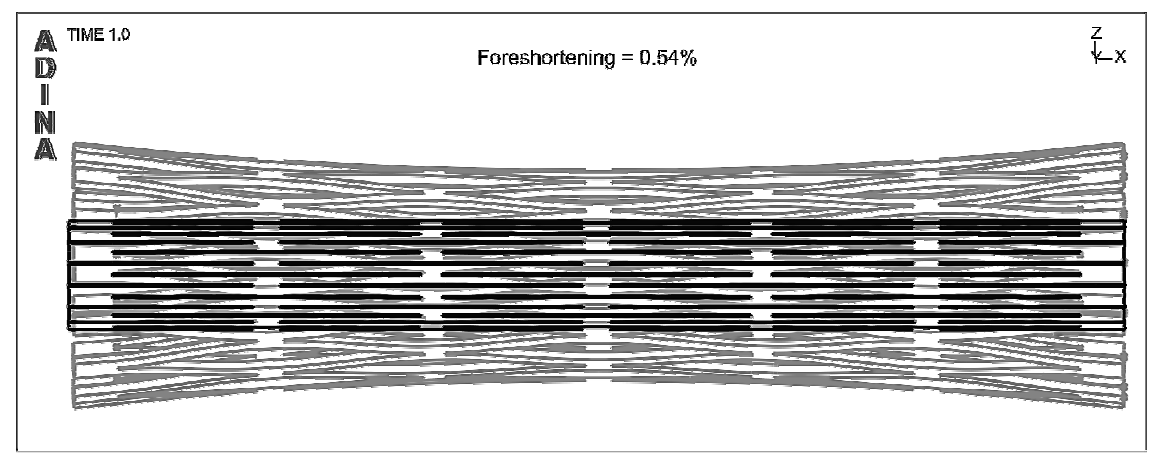

Fig. 6. Foreshortening of the Ti-13Nb-13Zr stent

The final stage of the study was to evaluate the increase in diameter in the beginning and at the end of the stent. For this purpose, the finite element method (FEM) was used for simulation of a transitional process of expansion for different structures of a stent expanded at internal pressure. Transitional and unequal expansion of the stent, termed dogboning, is one of the major causes of acute coronary arterial injuries. This type of damage in arteries is closely related to a restenosis in a stent. At this stage of the study, the relationship between stent load compared to the deformation curves was analysed in four places for all the considered stents (Fig. 7). Curve A0 represents the initial plane; A2 - a plane at $2 \mathrm{~mm}$ of the stent; A4 - at $4 \mathrm{~mm}$; A6 - central plane of the stent (6 mm on the length). Stent expansion occurred only through bending out of individual arms, without the use of connectors.

The analysis showed that with the increase in stent thickness, the increase in the diameter was reduced, whereas the rapid increases in implant diameter were first observed in the initial and final plane. For the relationships of stent load compared to deformation curves in four places presented for all materials, an insignificant increase in diameters in the A4 plane was observed, whereas the A2 plane showed the increase in diameters of $\Delta d=0.2 \mathrm{~mm}$. Analysis of the increases in the stent diameters for the material studied in the distal plane revealed that the lowest dogboning occurred for 15-segment stents with a wall thickness of $0.12 \mathrm{~mm}$. 
a)

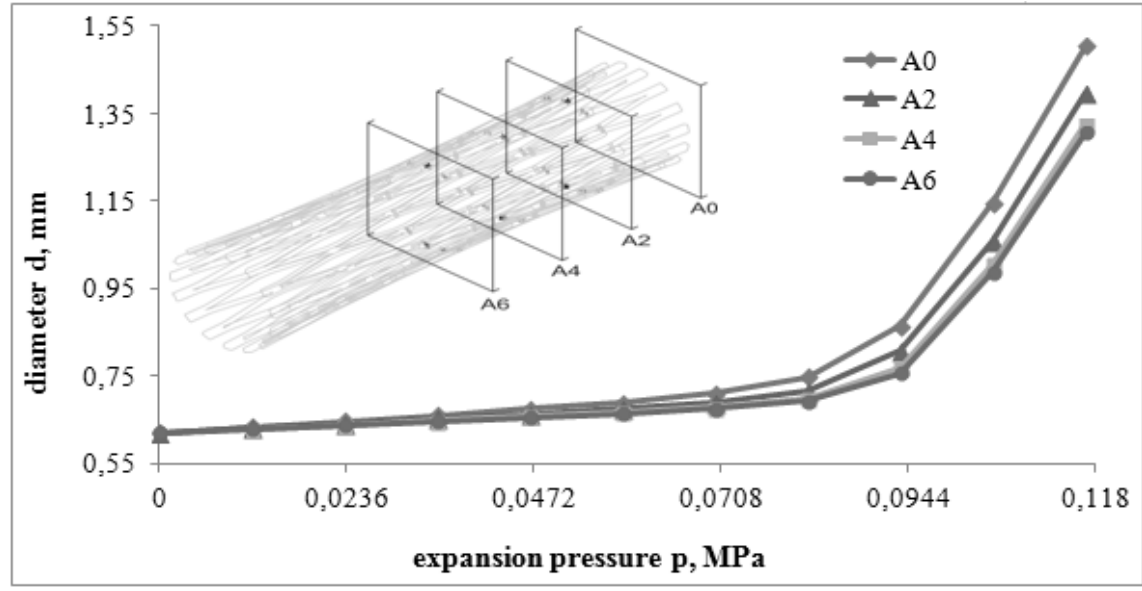

b)

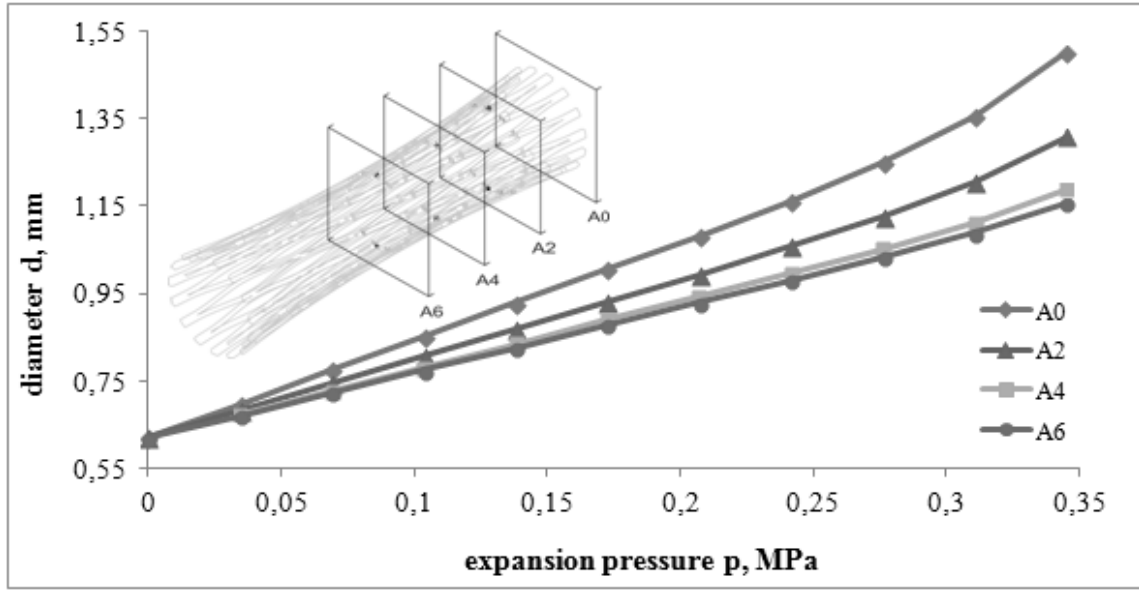

Fig. 7. Example diagrams of diameter vs. pressure for 15 -segment stent with wall thickness of $0.12 \mathrm{~mm}$ : a) for $\mathrm{Cr}-\mathrm{Ni}-\mathrm{Mo}$ steel, b) for Ti-6Al-7Nb alloy

The analysis showed that the group of 12-segment and 15-segment stents made of Cr-Ni-Mo steel and Co-Cr-W-Ni cobalt alloy should not represent potential limitations that lead e.g. to restenosis. Therefore, this group can be used for implantation of coronary arteries. In stents made of alloys based on titanium matrix (Ti-13Nb-13Zr and Ti-6Al-7Nb), only the group of 15-segment stents did not lead to vessel damage and can be used for implantation.

\section{Summary and final conclusions}

Mathematical models of blood flow in blood vessels and stents help evaluate the shape and materials for making this type of pipes. The models are so accurate that the US Food and Drug Administration, in order to limit the costs of expensive 
experiments, takes into consideration introduction of the requirement of mathematical modelling for stent design before performing any experiments. Precise modelling of the entire human vascular system extends beyond current computational capabilities. Therefore, researchers continue to focus their modelling efforts on small elements of this system, combined with simplified models of the rest of the whole system. Navier-Stokes equations are used to describe blood flow and their effect on vessel walls. Mathematical evidence was the main part of recent studies leading to the rejection of one type of stent and designing improved models. The current objective is to create computational models of fluid flow by vessels and stent models which allow for improvement of treatment and prediction of the diseases of the coronary artery (which represent the main cause of heart attack) [25].

In the present study, detailed mechanical characteristics of stents were determined using the finite element method. More specifically, stress and strain present in the stent were determined with respect to the pressure applied. Foreshortening and dogboning observed after stent expansion were also evaluated. The study took into consideration the models with two various numbers of segments and three different values of wall thickness. The analysis was carried out for four biomaterials: Cr-Ni-Mo austenitic steel, Co-Cr-W-Ni cobalt-matrix alloy and two titanium-matrix alloys: Ti-13Nb-13Zr and Ti-6Al-7Nb.

Numerical computations and analyses of obtained results led to the following conclusions:

- Design and choice of material for stents are important to the expansion procedure.

- Based on the analysis of the obtained results, change of stent geometry (increasing number of segments) minimizes the dogboning effect.

- The numerical analysis of stent foreshortening demonstrated that the obtained values of foreshortening remain within the ranges recommended in the standards.

- It was found that there is a relationship between the Young's modulus and the foreshortening or dogboning. Materials with a higher Young's modulus are characterized by lower dogboning and smaller shortening.

- Greater dogboning is observed in stents made of titanium alloys, although titanium alloys has a much lower Young's modulus compared to other analysed materials.

- The numerical simulations demonstrated that the values of stress and strain did not lead to stent damages.

- Higher expansion pressure was needed for extension of the stent with a lower number of segments.

- Due to the impossibility of performing the experiments, the study focused on virtual examinations using the finite element method.

- Numerical simulation performed using the computer technique turned out to be an effective tool for determination of accurate mechanical characteristics of stents. 
The conclusions result from the adopted goal and scope of the study. The problems discussed in the study are a very complex area of research. Therefore, it was impossible to take all aspects of stent implantation to the coronary arteries into consideration. Important objectives and solutions that help determine a number of parameters that are important for evaluation of clinical usefulness of a specific stent design were indicated.

With current development of technology, computers are a very common tool, which, using the software, allows for obtaining numerical equations that describe mathematically formulated engineering problems.

\section{References}

[1] Rojek J., Modelowanie i symulacja komputerowa złożonych zagadnień mechaniki nieliniowej metodami elementów skończonych i dyskretnych, IPPT PAN Warszawa 2007 (in Polish).

[2] Kleiber M. (ed.), Handbook of Computational Solid Mechanics, Springer-Verlag, Berlin 1998.

[3] Majchrzak E., Mochnacki B., Metody numeryczne. Podstawy teoretyczne, aspekty praktyczne i algorytmy, Wyd. II, Wyd. Politechniki Śląskiej, Gliwice 1996 (in Polish).

[4] Rakowski G., Kacprzyk Z., Metoda elementów skończonych w mechanice konstrukcji, Oficyna Wydawnicza Politechniki Warszawskiej, Warszawa 1993 (in Polish).

[5] Idziak-Jabłońska A., Stress and strain distribution in expanded coronary stents depending on applied material, Journal of Applied Mathematics and Computational Mechanics 2015, 14, 2, 21-30.

[6] ADINA Theory and Modeling Guide, Adina R\&D, INC. 1997.

[7] Idziak-Jabłońska A., Analiza numeryczna zjawisk mechanicznych w stentach wieńcowych, Praca doktorska, Politechnika Częstochowska, Wydział Inżynierii Mechanicznej i Informatyki, Częstochowa 2014 (in Polish).

[8] Bednarski T., Mechanika plastycznego płynięcia w zarysie, WN PWN, Warszawa 1995 (in Polish).

[9] Tammareddi S., Li Q., Effects of material on the deployment of coronary stents, Advanced Materials Research 2010, 123-125, 315-318.

[10] Bokota A., Modelowanie hartowania stali narzędziowych. Zjawiska cieplne, przemiany fazowe, zjawiska mechaniczne, seria Monografie nr 233, Wyd. Politechniki Częstochowskiej, Częstochowa 2012 (in Polish).

[11] Piekarska W., Bokota A., Numerical modeling of residual stresses in a dual laser beam welding, Metalurgija 2010, 49, 2, 156-160.

[12] Kalinowski L., Duda J., Matys A., Żelewski Ł. (eds.), Encyklopedia badań medycznych, Wydawnictwo Medyczne MAKmed, Gdańsk 1996 (in Polish).

[13] Norma PN-ISO 5832-1/1997, Wszczepy dla chirurgii. Materiały metalowe. Stal nierdzewna do przeróbki plastycznej.

[14] Norma PN-ISO 5832-6: 1997, Implants for surgery - Metallic materials - Part 6: Wrought cobalt-nickel-chromium-molybdenum alloy.

[15] Norma ASTM F 1295-11, Standard Specification for Wrought Titanium-6Aluminum-7Niobium Alloy for Surgical Implant Applications (UNS R56700).

[16] Norma ASTM F1713-08 (2013), Standard Specification for Wrought Titanium-13Niobium13Zirconium Alloy for Surgical Implant Applications (UNS R58130).

[17] Palmaz-Schatz stent made by Johnson and Johnson Company, Warren, NJ, USA, 1994. 
[18] Idziak-Jabłońska A., Lacki P., Analiza wpływu ilości segmentów i grubości stentu wieńcowego na jego właściwości mechaniczne, [in:] Mechanika w medycynie, eds. M. Korzyński, J. Cwanek, V. Liubimova, Oficyna Wydawnicza Politechniki Rzeszowskiej, Rzeszów 2012, 87-94 (in Polish).

[19] Migliavacca F., Petrini L., Colombo M., Auricchio F., Pietrabissa R., Mechanical behavior of coronary stents investigated through the finite element method, Journal of Biomechanics 2002, $35,803-811$.

[20] Idziak-Jabłońska A., Lacki P., Major R., Effect of material and geometry on dogboning in coronary stent, Inżynieria Materiałowa 2013, 4(194), 269-272.

[21] Idziak-Jabłońska A., Modelowanie zjawisk mechanicznych w stentach wieńcowych na podstawie analizy numerycznej, Mechanik 2015, 7, 303-310 (in Polish).

[22] Norma PN-EN ISO 25539-2 Implanty sercowo-naczyniowe - Wyroby wewnątrznaczyniowe Część 2: Stenty naczyniowe.

[23] Ciekot A., Idziak-Jabłońska A., Lacki P., Optimization of dogboning phenomenon of the coronary artery stent, Prace Naukowe Instytutu Matematyki i Informatyki Politechniki Częstochowskiej 2012, 2(11), 25-31.

[24] Idziak-Jabłońska A., Numerical analysis of mechanical phenomena in coronary stent made of titanium alloy Ti-13Nb-13Zr, Key Engineering Materials 2016, 687, 191-198.

[25] Canic S., Krajcer Z., Lapin S., Design of optimal endoprostheses using mathematical modeling, Endovascular Today 2006, May, 48-50. 